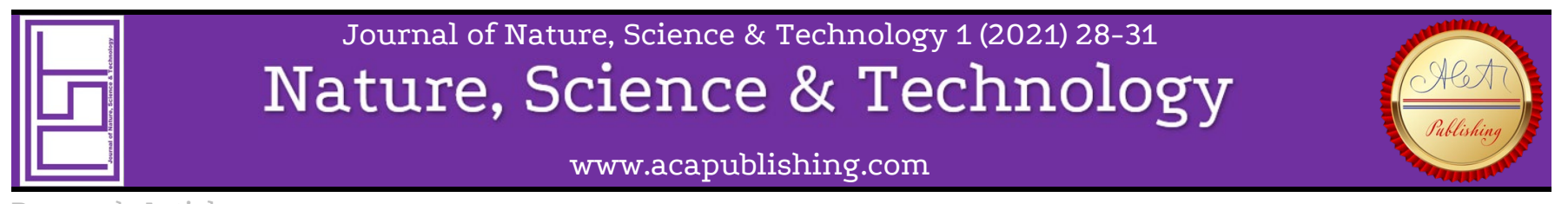

Research Article

\title{
Olive Processing Industry, How to Avoid or Minimize the Environmental Impact of Heavy Metals (Case Study: Albania)
}

\author{
Manjola Bani \\ Department of Chemistry, Faculty of Natural Sciences, University of Tirana, Tirana, Albania
}

\section{Keywords}

Olive Processing Industry,

Environmental Impact,

UV-VIS, Heavy Metals,

Liquid and Solid Waste,

Acidity.

\begin{abstract}
The development of olive production in Albania is considered as one of the priority branches of agriculture. After the 90s, the number of trees decreased significantly due to the abandonment of non-productive areas, but currently, there is a national plan to increase the planted area. According to forecasts to increase the amount of olives will increase the level of emissions. For this reason, the fate of application processing technologies with minimal impact on the environment should be emphasized. The analysis of these wastes is of interest because they are deposited on agricultural land, reducing productivity and thus affecting the country's economy. This study analyzes the environmental impact of the activity of olive oil processing lines, producing solid waste as secondary and liquid products. A processing plant in Lushnja, Albania was selected for this study. The factory uses 3-phase (3P) processing technology. Samples were taken during the intensive processing period in OctoberNovember 2020. Initially, samples were prepared for analysis, determined: number of solids, $\%$ of ash, carbon, acidity ( $\mathrm{pH}$ ), and conductivity. Heavy metals were determined at different wavelengths using UV-VIS spectrophotometers. The elements analyzed from the collected samples are $\mathrm{K}, \mathrm{Na}, \mathrm{Mg}, \mathrm{Cd}, \mathrm{Pb}, \mathrm{Zn}, \mathrm{Fe}, \mathrm{Cu}$. From the graph, the sample is characterized by increasing order: $\mathrm{Pb}<\mathrm{Cu}<\mathrm{Mg}<\mathrm{Fe}<\mathrm{Zn}<\mathrm{Cd}<\mathrm{Na}<\mathrm{K}$.
\end{abstract}

\section{Introduction}

Olive cultivation in our country is one of the earliest and most important agricultural activities. Albania is the country with the most optimal climate in the Mediterranean basin, where olive cultivation is sustainable alternatives. The development of olive production is considered as one of the priority branches of agriculture. After the 90's the number of trees decreased considerably due to the abandonment of non-productive surfaces, but currently has a national plan for increasing the area planted. According to forecasts to increase the amount of olive will increase the level of emissions soon. For this reason, it should be noted the fate of the application processing technologies with minimum impact on the environment. The analysis of these residues is of interest because they are deposited on agricultural land, reducing productivity and thus affecting the economy of the country. This study analyses the environmental impact of the activity of olive oil processing lines, producing solid waste as secondary products and liquid.

\section{Literature Review}

\subsection{Olive Tree}

Olive (Olea europaea) is a subtropical plant from the "Oleaceae" family. The Olive tree is a multi-year plant. Its origin is in the Eastern Mediterranean and today is known and spread across the globe. Olive is rich in calories, protein, fiber, vitamin A, vitamin B6, vitamin B, vitamin $\mathrm{C}$, magnesium, linolenic acid, oleic acid, calories, calcium, etc. The olive fruit is rich in oil, which is used as food and has healing properties. Mostly, olive fruit is used more for olive oil and less for table olives.

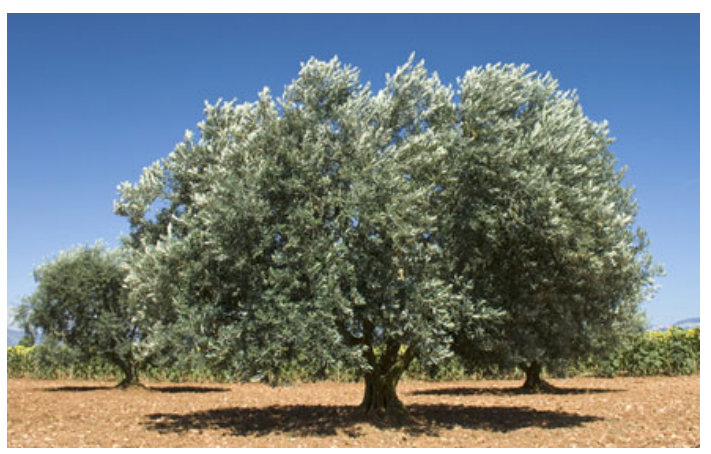

\subsection{Olive Fruit}

Figure 1: Olive tree

The fruit is composed of 3 parts: epicarp (outer skin), mesocarp (pulp), and endocarp (core).

Table 1: Chemical composition of olive fruit (\%)

\begin{tabular}{llll}
\hline Components & Pulp & Core & Essence \\
\hline Water & 60 & 9.2 & 30 \\
Oil & 30 & 0.8 & 27 \\
N-compounds & 3 & 3.3 & 10 \\
Sugar & 7.5 & 40 & 26 \\
Celullose & 6 & 38 & 1.8 \\
Minerals & 2 & 4 & 1.5 \\
Polyphenols & 3 & 0.3 & 0.5 \\
Others & - & 4.3 & 4.2 \\
compounds & & & \\
\hline
\end{tabular}

Received 19 Jan 2021 Revised 08 Feb 2021 Accepted 08 Feb 2021 Journal of Nature, Science\&Technology 1 (2021) 28-31
$2757-7783$ @) 2019 ACA Publishing. All rights reserved. https://doi.org/10.36937/janset.2021.001.005 


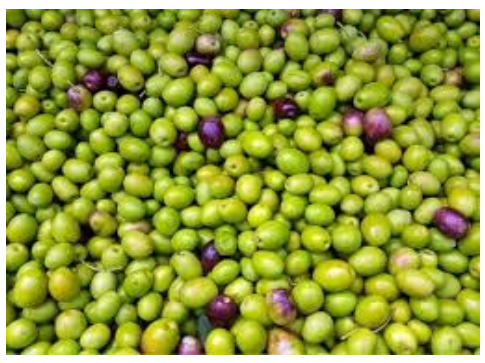

Figure 2: Olive Fruit

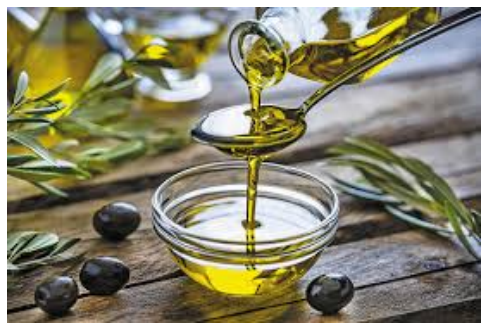

Figure 3: Olive Oil

\subsection{The Environmental Impact of Olive Processing Waste}

Olive cultivation and its processing industry produce large amounts of waste. According to official statistics, the cultivated area in Albania is approximately 41 thousand hectares. According to preliminary calculations only from the pruning stage, $27 \mathrm{~kg}$ each year is produced per olive tree. It is also estimated that $6.2 \%$ of the amount of fruit for processing is made up of leaves. From the processing process produced "desired product" olive oil at $25 \%$, semi-liquid residue in $35 \%$, and aqueous phase in $40 \%$. Olive oil production is characterized by considerable amounts of solid and liquid waste. Their deposition is a critical problem because according to various studies the discharge of liquid wastes into surface waters affects the reduction of their biodiversity.

The impact on the environment caused by the waste produced during the processing process has not been the focus. They are not reprocessed to add economic value and minimize the negative impacts on the environment. Vegetation waters are directly discharged into surface waters. They contain high levels of organic substances. Recently private entities are aware of the economic interest in processing this amount by building tanks for storing water that is produced before it is discharged and olive groves can be used as animal feed to obtain active coal of fruit etc. There is an opportunity to build an olive grove collection network to be extracted. But since it requires a certain investment, this is missing as a procedure. Currently, in Albania, it is difficult to apply minimal negative environmental impact schemes to deposit the residues because there are no practices of using olive oil for other purposes of obtaining the products but in most cases are used as animal feed or for burning. In our country, the olive processing technology is dominated by that 3-phase and this technology is an important contributor to water discharges.

\section{Methodology}

For this study was selected a processing factory in Lushnja, Albania. The factory uses 3-phase processing technology (3P). Samples were taken in the period of intensive processing in September-October 2020. Initially, samples were prepared for analysis, are placed in the oven at $500 \pm 15^{\circ} \mathrm{C}$ for 3 hours and dried in the thermostat at $100 \pm 5^{\circ} \mathrm{C}$ temperature and it was determined: the number of solid materials, \% of ash, carbon, acidity $(\mathrm{pH})$ and conductivity. Heavy metals were determined at different wavelengths using the Spectrophotometers UV-VIS. The elements analyzed by the collected samples are $\mathrm{K}, \mathrm{Na}, \mathrm{Mg}$, $\mathrm{Cd}, \mathrm{Pb}, \mathrm{Zn}, \mathrm{Fe}, \mathrm{Cu}$. It calculated the total \% of solids, ash content in $\%$, carbon content, conductivity, and $\mathrm{pH}$.
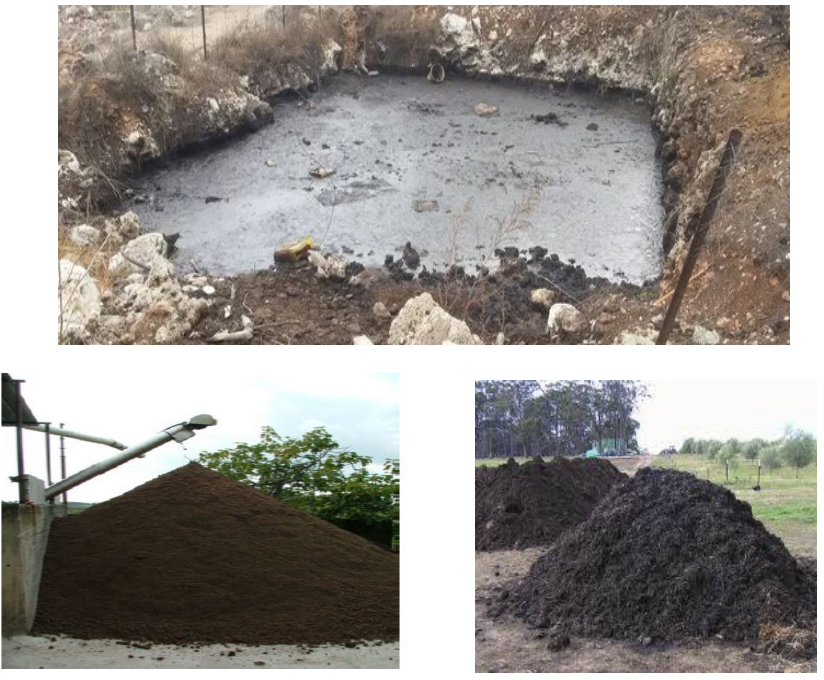

Figure 4: Liquid and solid waste of olive processing industry

Table 2: The results of the elements

\begin{tabular}{|c|c|}
\hline \multicolumn{2}{|c|}{ K standard 1 ppm } \\
\hline & 0.089 \\
\hline $\begin{array}{l}\text { PB (white test) } \\
\text { St (Standard) }\end{array}$ & 0.256 \\
\hline Samples & 0.741 \\
\hline \multirow[t]{2}{*}{ Subtraction of Absorbance } & $0.167(\mathrm{~PB})$ \\
\hline & $0.652(\mathrm{St})$ \\
\hline Concentration (ppm) & 3.904 \\
\hline $\begin{array}{l}\text { Concentration } \\
(\mu \mathrm{g} / \mathrm{g}) \text { or }(\mathrm{mg} / \mathrm{kg})\end{array}$ & 390.4 \\
\hline \multicolumn{2}{|c|}{ Na standard $1 \mathrm{ppm}$} \\
\hline & 0.091 \\
\hline $\begin{array}{l}\text { PB (white test) } \\
\text { St (Standard) }\end{array}$ & 0.260 \\
\hline \multicolumn{2}{|l|}{ Samples } \\
\hline Subtraction of Absorbance & $\begin{array}{l}0.169(\mathrm{~PB}) \\
0.478(\mathrm{St})\end{array}$ \\
\hline \multicolumn{2}{|l|}{ Concentration (ppm) } \\
\hline $\begin{array}{l}\text { Concentration } \\
(\mu g / g) \text { or }(\mathrm{mg} / \mathrm{kg})\end{array}$ & 282.8 \\
\hline \multicolumn{2}{|c|}{ Mg standard 1 ppm } \\
\hline \multirow{4}{*}{$\begin{array}{l}\text { PB (white test) } \\
\text { St (Standard) } \\
\text { Samples } \\
\text { Subtraction of Absorbance }\end{array}$} & 0.198 \\
\hline & 0.212 \\
\hline & $0.110(\mathrm{~PB})$ \\
\hline & $0.124(\mathrm{St})$ \\
\hline Concentration (ppm) & 1.127 \\
\hline $\begin{array}{l}\text { Concentration } \\
(\mu g / g) \text { or }(\mathrm{mg} / \mathrm{kg})\end{array}$ & 112.7 \\
\hline \multicolumn{2}{|c|}{ Cd standard $1 \mathrm{ppm}$} \\
\hline $\begin{array}{l}\text { PB (white test) } \\
\text { St (Standard) }\end{array}$ & 0.260 \\
\hline \multicolumn{2}{|l|}{ Samples } \\
\hline Subtraction of Absorbance & $\begin{array}{l}0.205(\mathrm{~PB}) \\
0.508(\mathrm{St})\end{array}$ \\
\hline Concentration (ppm) & 2.478 \\
\hline $\begin{array}{l}\text { Concentration } \\
(\mu \mathrm{g} / \mathrm{g}) \text { or }(\mathrm{mg} / \mathrm{kg})\end{array}$ & 247.8 \\
\hline
\end{tabular}




\section{Findings and Discussion}

The elements analyzed by the collected samples are $\mathrm{K}, \mathrm{Na}, \mathrm{Mg}, \mathrm{Cd}, \mathrm{Pb}$, $\mathrm{Zn}, \mathrm{Fe}, \mathrm{Cu}$. Were measured absorbance of PB (white test), standards, and samples and were calculated the concentration of each metal (knowing that we took $2 \mathrm{~g}$ of dried sample and diluted it in $100 \mathrm{ml}$ balloon).

\begin{tabular}{|c|c|}
\hline \multicolumn{2}{|c|}{ Pb standard $1 \mathrm{ppm}$} \\
\hline $\begin{array}{l}\text { PB (white test) } \\
\text { St (Standard) }\end{array}$ & $\begin{array}{l}0.017 \\
0.310\end{array}$ \\
\hline Samples & 0.047 \\
\hline Subtraction of Absorbance & $\begin{array}{l}0.293(\mathrm{~PB}) \\
0.03(\mathrm{St})\end{array}$ \\
\hline Concentration (ppm) & 0.102 \\
\hline $\begin{array}{l}\text { Concentration } \\
(\mu g / g) \text { or }(\mathrm{mg} / \mathrm{kg})\end{array}$ & 10.2 \\
\hline \multicolumn{2}{|c|}{ Zn standard 1 ppm } \\
\hline & 0.093 \\
\hline $\begin{array}{l}\text { PB (white test) } \\
\text { St (Standard) }\end{array}$ & 0.231 \\
\hline Samples & 0.310 \\
\hline Subtraction of Absorbance & $\begin{array}{l}0.138(\mathrm{~PB}) \\
0.217(\mathrm{St})\end{array}$ \\
\hline Concentration (ppm) & 1.572 \\
\hline $\begin{array}{l}\text { Concentration } \\
(\mu g / g) \text { or }(m g / k g)\end{array}$ & 157.2 \\
\hline \multicolumn{2}{|c|}{ Fe standard $1 \mathrm{ppm}$} \\
\hline $\begin{array}{l}\text { PB (white test) } \\
\text { St (Standard) }\end{array}$ & $\begin{array}{l}0.002 \\
0.177\end{array}$ \\
\hline Samples & 0.215 \\
\hline Subtraction of Absorbance & $\begin{array}{l}0.175(\mathrm{~PB}) \\
0.213(\mathrm{St})\end{array}$ \\
\hline Concentration (ppm) & 1.217 \\
\hline $\begin{array}{l}\text { Concentration } \\
(\mu g / g) \text { or }(\mathrm{mg} / \mathrm{kg})\end{array}$ & 121.7 \\
\hline \multicolumn{2}{|c|}{ Cu standard 1 ppm } \\
\hline $\begin{array}{l}\text { PB (white test) } \\
\text { St (Standard) }\end{array}$ & $\begin{array}{l}0.004 \\
0.023\end{array}$ \\
\hline Samples & 0.017 \\
\hline Subtraction of Absorbance & $\begin{array}{l}0.019(\mathrm{~PB}) \\
0.017(\mathrm{St})\end{array}$ \\
\hline Concentration (ppm) & 0.894 \\
\hline $\begin{array}{l}\text { Concentration } \\
(\mu \mathrm{g} / \mathrm{g}) \text { or }(\mathrm{mg} / \mathrm{kg})\end{array}$ & 89.4 \\
\hline
\end{tabular}

The data received is presented graphically:

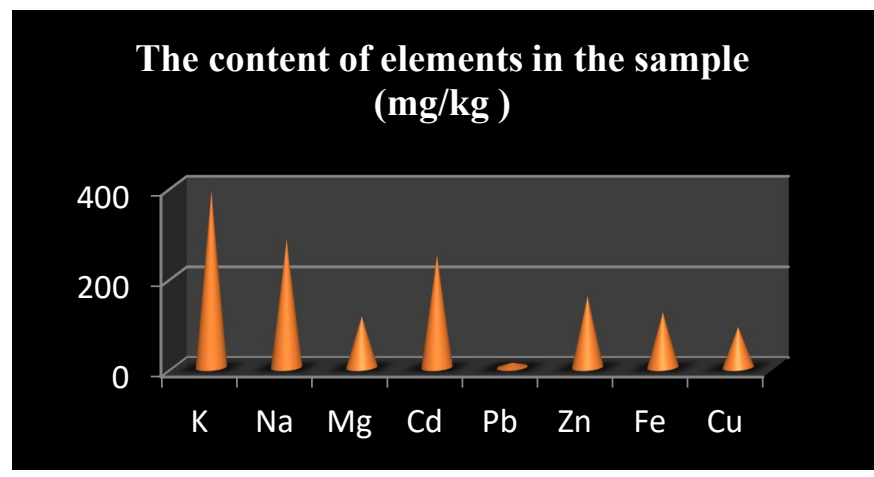

Figure 5: Graphic presentation of sample concentrations expressed in $\mathrm{mg} / \mathrm{kg}$

From the graphic presentation the sample is characterized by increasing order: $\mathrm{Pb}<\mathrm{Cu}<\mathrm{Mg}<\mathrm{Fe}<\mathrm{Zn}<\mathrm{Cd}<\mathrm{Na}<\mathrm{K}$. Lead resulted in lower content than the detection limit (KD) of the method (0.048 ppm), so less than $0.6 \mathrm{mg} / \mathrm{kg}$. The elements potassium (K), sodium (Na), iron (Fe), referred to natural origin from soils, $\mathrm{Mg}, \mathrm{Zn}, \mathrm{Cd}$ with a gas origin. The $\mathrm{Cu}$ and $\mathrm{Pb}$ elements originate from tire burning, so the impact is small. The liquid samples were analyzed at the point of discharge of the point taken in the study. The device used was a universal $\mathrm{pH}$ meter, the $\mathrm{pH}$ value was 5.17 and the dissolved $\mathrm{O} 2$ (mg / l) resulted from 1.53. The temperature at which the measurement was carried out was $15^{\circ} \mathrm{C}$. If the $\mathrm{pH}$ values of liquid discharges are compared with several categories of natural water such as groundwater and surface waters (6.5 to 8.5), rainwater (5.5 to 6.0 ), seawater approximately 8.0 , it results that these discharges are of the acidic category.

\section{Conclusions}

This study analyzed the environmental impact of the activity of olive oil processing lines, producing solid waste as secondary products and liquid. This study deals with an actual problem related to the negative effects on the environment from the activity of this industry making this issue more present. For this study was selected a processing factory in Lushnja, Albania. The factory used 3-phase processing technology (3P). Samples were taken in the period of intensive processing in September-October 2020. Heavy metals were determined at different wavelengths using the Spectrophotometers UV-VIS. The elements analyzed by the collected samples are $\mathrm{K}, \mathrm{Na}, \mathrm{Mg}$, $\mathrm{Cd}, \mathrm{Pb}, \mathrm{Zn}, \mathrm{Fe}, \mathrm{Cu}$. From the graphic, the sample is characterized by increasing order: $\mathrm{Pb}<\mathrm{Cu}<\mathrm{Mg}<\mathrm{Fe}<\mathrm{Zn}<\mathrm{Cd}<\mathrm{Na}<\mathrm{K}$. Elements $\mathrm{K}, \mathrm{Na}, \mathrm{Fe}$ refer to natural earth origin, $\mathrm{Mg}, \mathrm{Zn}$, Cd of gas origin, atmospheric depositions affect the change of cations content in these plantations. Elements $\mathrm{Cu}$ and $\mathrm{Pb}$ have origin from tire burning.

\section{Recommendations}

The olive processing industry in Albania after the '90s passed from state ownership to private ownership. As a result, the processing lines have been widely spread and unproven, causing inadequate management of solid and liquid olive residues. In this context, we recommend:

Reuse of liquid and solid wastes.

Liquid waste can be used for irrigation at a permissible value of $800 \mathrm{~m} 3$ / ha with origin from three-phase lineage by building tanks for storing water produced before it is discharged.

In the case of solid waste, can be built a collection network built for the re-acquisition of residual oil quantities by introducing them into processing schemes to increase the economic value of this industry and to minimize the negative impact on the environment.

$>\quad$ Olive herbs produced can be used as animal feed, to obtain active coal from the fruit nucleus or in other cases may be used for combustion by various private entities.

Subventions for farmers

$>$ Use of processing machines with advanced technology and their rehabilitation. 


\section{Declaration of Conflict of Interests}

The authors declare that there is no conflict of interest. They have no known competing financial interests or personal relationships that could have appeared to influence the work reported in this paper.

\section{References}

[1.] INSTAT, Olive Commodity, (2015-2020).

[2.] Topi, D, Thomaj, F, Beqiraj, I, Seiti, B, Halimi, E, Hysa, O. Expansion of the olive extraction industry in Albania (2000).

[3.] S.Vitolo, L.Petarca, B.Bresci, Bioresource Technology (2000)

[4.] Anastasiou, Ch, Christou, P, Michael, A, Nicolaides, D, ,Lambrou,Th Environmental Research Journal 5(2011).

[5.] Amiot, M. Fleuriet, A, Macheix, J. Accumulation of oleuropein derivatives during olive maturation, Phytochemistry (1989).

[6.] Bani, M.Environmental Impact of COVID-19 Pandemic (2020).

[7.] Park, SM \& Shin, SY \& Yang, JS \& Ji, SW \& Baek, K..Selective recovery of dissolved metals from mine drainage using electrochemical reactions. Electrochimica Acta (2015).

[8.] Nleya, Y \& Simate, GS \& Ndlovu, S 2016. Sustainability assessment of the recovery and utilization of acid from acid mine drainage.Journal of Cleaner Production (2016).

[9.] Masindi, V\& Gitari, MW \&Tutu, H.Passive Remediation of Acid Mine Drainage. LAP Lambert Academic Publishing (2016).

[10.] Simate, GS \& Ndlovu, S. Acid mine drainage: Challenges and opportunities. Journal of Environmental Chemical Engineering (2014).

[11.] Silvas, FPC \& Buzzi, DC \& Espinosa, DCR \& Tenório, JAS. Biosorption of AMD metals using Rhodococcus opacus. Revista Escola de Minas (2011)

[12.] Soleimani, $M$ \& Amini, $N$ \& Sadeghian, B \& Wang, D \& Fang, $\mathrm{L}$ Heavy metals and their source identification in particulate matter (PM2.5) in Isfahan City, Iran. Journal of Environmental Sciences (2018).

[13.] [13.] Ventura, LMB \&Mateus, VL \& Wanderley, KB \& Taira, FT \&Saint'Pierre, TD \&Gioda, A. Chemical composition of fine particles (PM2.5): Water-soluble organic fraction and trace metals. Air Quality, Atmosphere and Health (2017).
[14.] Nleya, Y \&Simate, GS \&Ndlovu, S. Sustainability assessment of the recovery and utilization of acid from acid mine drainage. Journal of Cleaner Production (2016).

[15.] Athar, M \&Vohora, SB.Heavy Metals and Environment. New Delhi: New Age International (P) Limited (2001).

[16.] Musilova, J \&Arvay, J \& Vollmannova, A \& Toth, T \&Tomas, J.Environmental contamination by heavy metals in a region with previous mining activity.Bulletin of Environmental Contamination and Toxicology (2016).

[17.] Lee, G \&Bigham, JM \&Faure, G.Removal of trace metals by coprecipitation with $\mathrm{Fe}, \mathrm{Al}$ and $\mathrm{Mn}$ from natural waters contaminated with acid mine drainage in the Ducktown Mining District, Tennessee. Applied Geochemistry (2002).

[18.] Lepp, NW.Effect of heavy metal pollution on plants. Metals in the Environment, Pollution Monitoring Series, Applied Science Publishers.Department of Biology. Liverpool, United Kingdom: Liverpool Polytechnic (2012).

[19.] Banfalvi, G.Cellular Effects of Heavy Metals. Netherlands, London, New York: Springer (2011).

[20.] Wong, MH. Environmental Contamination: Health Risks and Ecological Restoration. United States of America: Taylor \& Francis Group (2012).

[21.] Salomons, W \& Forstner, U \&Mader, P. Heavy Metals: Problems and Solutions. Berlin, Germany: Springer-Verlag (1995).

[22.] El-Shahawi, MS \& Hamza, A \&Bashammakhb, AS \&Al-Saggaf, WT.An overview of the accumulation, distribution, transformations, toxicity, and analytical methods for the monitoring of persistent organic pollutants. Talanta (2020).

[23.] Park, S-M \&Shin, S-Y\&Yang, J-S \& Ji, S-W \& Baek, K. Selective recovery of dissolved metals from mine drainage using electrochemical reactions. Electrochimica Acta (2015).

\section{How to Cite This Article}

Bani, M, Heavy Metals, How to Avoid or Minimize their Toxicity in the Environment and Human Health, Journal of Nature, Science \& Technology, 1(2021), 28-32.

https://doi.org/10.36937/janset.2021.001.005 